\title{
Histological organization and microarchitecture of various cells lining the olfactory epithelium of Rita rita (Hamilton, 1822) (Siluriformes: Bagridae)
}

\author{
SAROJ KUMAR GHOSH and PADMANABHA CHAKRABARTI
}

Fisheries Laboratory, Department of Zoology, The University of Burdwan, Burdwan 713 104,

West Bengal, India

Corresponding Author: Padmanabha Chakrabarti,dr.pchakrabarti@yahoo.in

(Received on 18 May 2011; Accepted on 15 November 2011)

\begin{abstract}
Rita rita is a carnivorous, bottom dwelling catfish inhabits in muddy dirty water and depends on olfactory sensation for procurement of food. The structural organization and function of various cells lining its olfactory epithelium have been investigated by light and scanning electron microscopy. The elongated olfactory organ consists of 64-68 primary lamellae arising from a narrow median raphe. Sensory as well as non-sensory regions are distinctly oriented on each olfactory lamella. The sensory epithelium occupies the apical tongue-shaped area and basal part of the olfactory lamellae, whereas the middle part is covered with non-sensory epithelium. The sensory epithelium is composed of 2 types of dendrites of receptor cells (either ciliated or microvillous), labyrinth cells, and a large number of flagellated supporting cells. The non-sensory epithelium is made up of stratified epithelial cells having a different pattern of microridges and mucous cells. Variations in the cellular orientation of the various cells on the olfactory epithelium have been correlated with the functional views of the fish concerned.
\end{abstract}

Keywords: cellular architecture, scanning electron microscopy, olfactory organ, Rita rita

\section{INTRODUCTION}

In fish, water passes into the olfactory chamber through the nostrils, and chemicals dissolved in the water infiltrate olfactory cells (MA \& WANG 2010). Therefore, the olfactory organ is the only organ of fish in which receptor neurons are directly exposed to the aquatic environment and is vulnerable to water contaminants. A number of researchers have studied the enormous diversity of olfactory rosette in teleosts, regarding the shape, number, variations in olfactory lamellae at various ages, and distribution of sensory and non-sensory epithelium under a light microscope $\left(\mathrm{J}_{\mathrm{A}-}\right.$ KUBOWSKI 1981; ZeISKE et al. 1987; MANDAL et al. 2005; FerRANDO et al. 2007; GHOSH \& Chakrabarti 2009, 2010). As a complement of those studies, the fine anatomical structure of the olfactory epithelium of teleosts have been investigated by various 
authors (Doroshenko \& Motavkin 1986; Ruzhinskaya et al. 2001; Chakrabarti \& Ghosh 2010; MA \& WANG 2010). Their results show that the olfactory rosettes are relatively simple structures, comprising a mosaic of receptor cells arranged between other non-receptor cells, which correlate with the enormous diversity of life styles among fishes. The fishes that have few lamellae on the olfactory rosette are termed microsmatic, while those with a large number of lamellae are termed macrosmatic (GON \& Fishelson 2009).

The purpose of the present study is to describe in detail the histology and surface architecture of the olfactory epithelium of Rita rita (Hamilton, 1822). It is a sluggish, bottom-dwelling, carnivorous catfish, which subsists on molluscs, insects, crustaceans, and small fish in South Asiatic rivers (YASHPAL et al. 2006). Olfactory epithelium plays a major role in detecting the odoriferous substances in all ecosystems, which is crucial for food detection and coordination of reproductive behaviours.

\section{MATERIALS AND METHODS}

Twenty healthy adult individuals of $R$. rita (22-24 cm in length) were obtained from the river Ganges in March-December 2010. The fishes were anesthetized under benzocaine $(4 \mathrm{mg} / \mathrm{L})$. Olfactory rosettes were dissected out from the dorsal side of the olfactory chamber under a stereo microscope.

For histological studies, the tissues were fixed in aqueous Bouin's fluid for 16$18 \mathrm{~h}$ and subsequently dehydrated properly through an ascending series of ethyl alcohol. The tissues were cleared with xylene, embedded in paraffin wax $\left(56-58^{\circ} \mathrm{C}\right)$ and cut at $4 \mu \mathrm{m}$ thickness. The sections were stained with Mallory's triple stain.

For scanning electron microscopy (SEM), the olfactory rosettes were perfused in vivo with $2.5 \%$ glutaraldehyde solution in $0.1 \mathrm{M}$ phosphate buffer $(\mathrm{pH} 7.4)$ for $20 \mathrm{~min}$. The entire olfactory rosettes were dissected out and rinsed with heparinised saline (heparin sodium salt $10000 \mathrm{IU}$ dissolved in $0.67 \% \mathrm{NaCl}$ solution) to remove the adhering mucus. After rinsing in $0.1 \mathrm{M}$ phosphate buffer $(\mathrm{pH} 7.4)$, the tissues were again fixed with $2.5 \%$ glutaraldehyde in $0.1 \mathrm{M}$ phosphate buffer $(\mathrm{pH} 7.4)$ for $24 \mathrm{~h}$ at $4{ }^{\circ} \mathrm{C}$. After fixation the tissues were removed, rinsed repeatedly in the same buffer ( $\mathrm{pH} 7.4$ ) and post-fixed in $1 \%$ osmium tetroxide in $0.1 \mathrm{M}$ phosphate buffer ( $\mathrm{pH}$ 7.4) for $2 \mathrm{~h}$. The tissues were washed thoroughly in the same buffer and dehydrated through a graded series of acetone, followed by isoamyl acetate and subjected to critical point drying. Dried samples were mounted on metal stubs, coated with gold palladium with a thickness of approximately $20 \mathrm{~nm}$, and viewed under a Hitachi S530 scanning electron microscope.

\section{RESULTS}

According to SEM observations, the elongated olfactory rosette of $R$. rita consists of a series of 64-68 primary lamellae on each side (left and right) of the median narrow raphe. The outer margins of the lamellae are free, while the inner margins are attached to the raphe (Fig. 1). The apical parts of the lamellae are flat and almost tongue-shaped, but the middle parts and bases are narrow (Fig. 1). Each olfactory 

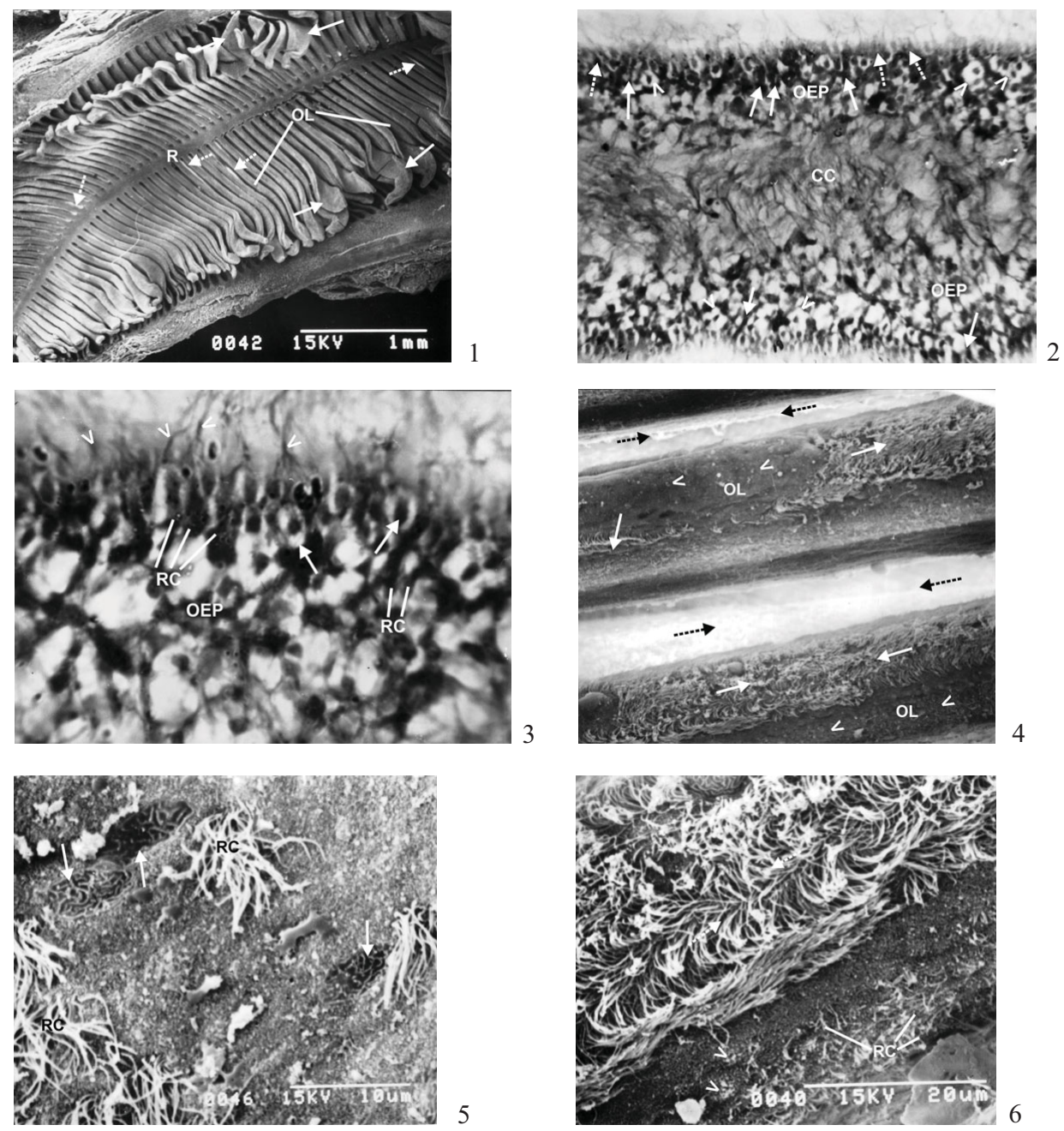

Figs. 1-6. Micrographs of the olfactory epithelium of Rita rita, taken using scanning electron microscopy (SEM) or histological sections stained with Mallory's triple (MT) stain: (1) elongated olfactory rosette exhibiting various shapes of olfactory lamellae (OL) radiating from the median raphe (R), solid arrows indicate the tongue-shaped apical sensory part of OL, broken arrows indicate the sensory part in the basal region of OL $(\mathrm{SEM}) \times 30$; (2) transverse section of olfactory lamellae showing sensory olfactory epithelium (OEP) separated by a wide central core (CC), note the presence of receptor cells (arrows), flagellated non-sensory cells (broken arrows) and labyrinth cells (arrow heads). (MT) $\times 400$; (3) transverse section of olfactory lamellae showing OEP with flagellated supporting cells (arrow heads), receptor cells (RC) and labyrinth cells (solid arrows), $(\mathrm{MT}) \times 1000$. (4) longitudinal folds of olfactory lamella (OL) leaving long furrows between them (broken arrows), Note the presence of prominent receptor (solid arrows) and non-receptor areas (arrow heads), (SEM) $\times 500$; (5) surface of OEP showing dendrite processes of ciliated RC, arrows indicate labyrinth cells, $(\mathrm{SEM}) \times 3000$; (6) sensory epithelium of OL showing ciliated RC and microvillous cells (arrow heads) surrounded by a dense mat of flagellated non-sensory cells (broken arrows $),(\mathrm{SEM}) \times 2000$ 

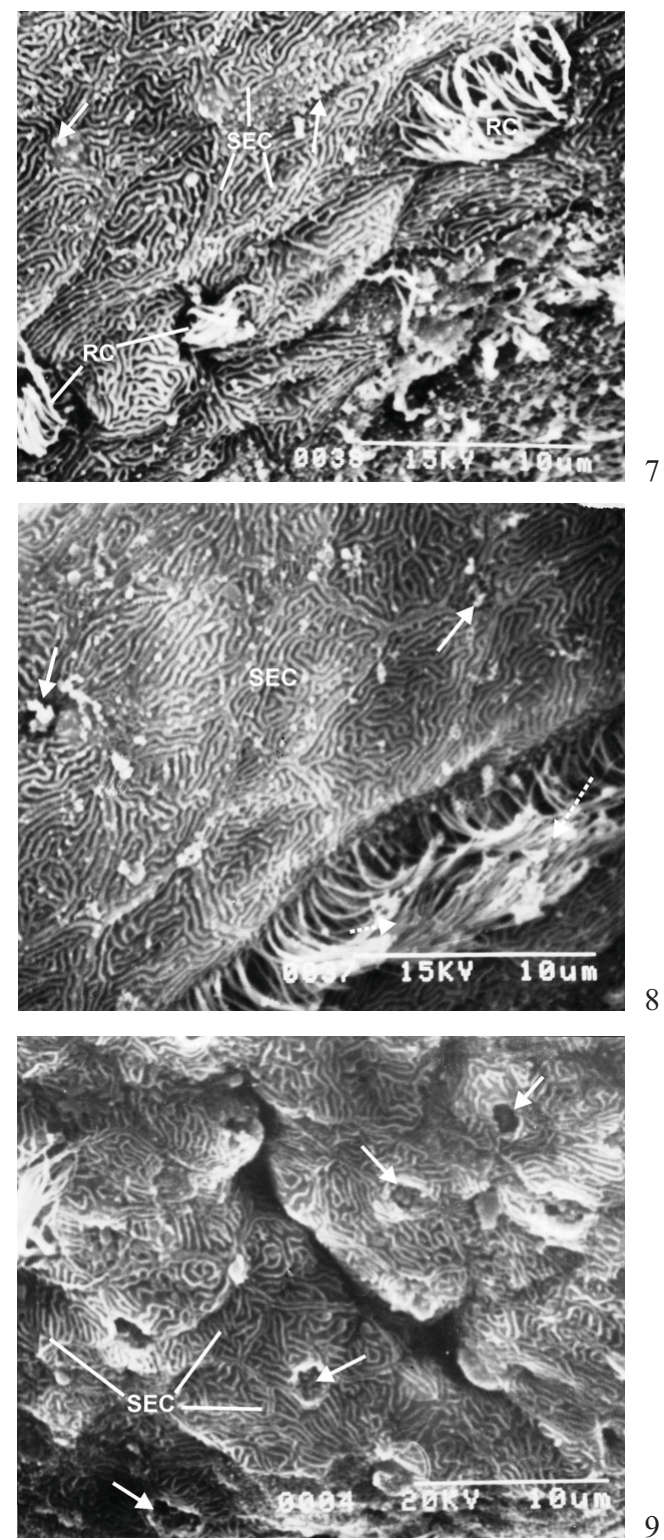

Figs. 7-9. Micrographs of the olfactory epithelium of Rita rita, taken using scanning electron microscopy (SEM): (7) Transitional zone of sensory and non-sensory olfactory epithelium lined with crowded stratified epithelial cells (SEC) having labyrinth-pattern microridges, note the presence of tufts of ciliated receptor cells (RC) in between SEC, arrows indicate openings of mucous cells, $(\mathrm{SEM}) \times 4000 ;(8)$ middle portion of olfactory lamella $(\mathrm{OL})$ showing densely packed SEC bordered by flagellated supporting cells (broken arrows), arrows indicate openings of mucous cells, (SEM) $\times 5000$; (9) surface epithelium of the raphe, represented by various shapes of SEC, having a complicated pattern of microridges, note the presence of openings of mucous cells with secreted mucin (arrows), $(\mathrm{SEM}) \times 5000$ 
lamella bears a broad space of receptor area on the apical tongue-shaped region and a small aggregation of receptor area in between the base of the lamella. The non-sensory epithelium covers mainly the lateral surface of the middle region of each olfactory lamella (Fig. 1). Histologically, the olfactory lamellae are composed of 2 layers of epithelium separated by a wide central lamellar space, the central core, which contains connective tissue (Fig. 2). The olfactory epithelium is composed of mixed sensory and many flagellated non-sensory cells, mucous cells, and labyrinth cells (Figs. 2-3). Receptor cells are intermingled with the flagellated supporting cells. The dendrite of each receptor cell runs to the surface of the olfactory epithelium as a narrow and cylindrical process. The labyrinth cells are scattered in the superficial layer of the olfactory epithelium. They are ovoid or rounded in outline with prominent nuclei. The flagellated supporting cells are located in the upper region of the olfactory epithelium, in between receptor cells, and are oval, containing elongated nuclei (Fig. 3). According to SEM observations, the olfactory epithelial surface is provided with prominent longitudinal folds, leaving long furrows between them. The prominent receptor and non-receptor areas are clearly discernible in the longitudinal folds (Fig. 4). At a higher magnification, the dendritic process of primary receptor cell of sensory epithelium end with a tuft of ciliated processes (Fig. 5). However, a few labyrinth cells are also detected in between the tuft of receptor cells, which are almost similar to chloride cells in the gill epithelium (Fig. 5).

On the contrary, under SEM observation, the basal portion of lamella is provided with scattered microvillous receptor cells and ciliated sensory cells surrounded by a dense mat of flagellated non-sensory cells (Fig. 6). The transitional zone of sensory and non-sensory epithelium is mainly lined with stratified epithelial cells with labyrinth-pattern microridges and intercalated with patches of free dendrite processes of sensory receptor cells (Fig. 7). The surface epithelium of the lamella in the middle region is composed of crowded stratified epithelial cells interspersed with mucous cells. The outer margins of the epithelial cells are provided with flagellar processes of supporting cells (Fig. 8). The surface epithelium of the raphe is represented by various heights of stratified epithelial cells having labyrinth-pattern microridges. The openings of mucous cells with mucin mass are located in between stratified epithelial cells (Fig. 9).

\section{DISCUSSION}

The olfactory epithelium in fish has an acute sense of smell in various aspects of their life history and shows considerable diversity, reflecting the degree of development and ecological habitats (ZeISKE et al. 1992). The present study reveals that the elongated olfactory rosette of $R$. rita consists of 64-68 primary lamellae in each left and right rosette arranged on either side of the long and narrow raphe. Thus the total olfactory area of this fish is considerably greater than the total retinal area. This entails that it belongs to TeichmanN's (1954) group of nose fishes, comprising solitary and nocturnal predators (BANNISTER 1965). The distribution of the sensory and nonsensory epithelia on the surface of the lamellae shows a great variety in fish species (YАмАмото 1982). In the present study the sensory receptor epithelium is mainly 
restricted to the apical flat tongue-like portion of the lamellae and the basal lamellar portion, while the middle portion of the lamellae is provided with non-sensory epithelial cells. This is a unique feature of the olfactory epithelium in this fish occupying a specific ecological niche and thus mobilizing different olfactory cues. HARA and ZiELINSKI (1989) also identified definite aggregations of ciliated receptor cells and confirmed their olfacto-sensory functions. In the sensory epithelium, the cilia of the supporting cells create a slow current of water across the olfactory lamellae, which remove the remains of the stimulating substances and keeps the receptor cells ready for new stimuli. Adequate ventilation is necessary to bring about the odorants in the olfactory chamber for perceiving the chemical signals (Doving et al. 1977; BELANGER et al. 2003). In the present study the receptor epithelium of $R$. rita consists of ciliated, microvillous, and labyrinth cells. However, the ciliated receptor cells dominated over the microvillous receptor cells. ZEISKE et al. (2003) observed that the ciliated and microvillous receptor cells occur together in the olfactory organ of the genus Acipenser but the proportions differ between species. The ciliated receptor cells are of special interest because they form a part of the olfactory transduction mechanism, are stimulated by odour-bearing substances, and enable the fish to detect food. In $R$. rita the microvillous receptor cells consist of minute dendrites having a slightly sunken apex, and in contrast to the ciliated receptor cells may be involved in the transduction mechanism for pheromones in the environment. BHUTE and BAILE (2007) also advocated that the receptor neurons of the crypt microvillous cells perceive and process signals of pheromone, which is an important step of breeding in Labeo rohita. The labyrinth cells on the surface of sensory epithelium of the riverine fish $R$. rita may serve as excretory cells for osmoregulation and ion regulation. In this way they may cause the olfactory organs to function optimally in water of various salinities. SHIRAI and UTIDA (1970) suggested that the labyrinth cells may be involved in electrolyte transport because they are structurally similar to the chloride cells found in fish gills. RUZHINSKAYA et al. (2001) also demonstrated the presence of typical chloride cells in the olfactory epithelium of Acipenser maerii, A. ruthenus, Salmo gairdneri, Carassius auratus, C. carassius, Perca fuviatilis, and Oreochromis mossambicus. Those authors also reported that such cells are present in the areas of both non-sensory and sensory epithelium and provide the active transport of ions between the inner and outer media, in order to maintain ion and osmotic homeostasis. In the transitional zone of receptor and non-receptor epithelium, few scattered tufts of receptor dendrites are responsible for better monitoring of water quality even up to this zone.

The apical surface of the non-sensory epithelium is provided with flagellated supporting cells, which are responsible for creating a water current in the olfactory chamber as well as the lamellar surface for smooth flow of water in the olfactory chamber. Furthermore, the non-sensory epithelium and the epithelium of the raphe consist of stratified epithelial cells with labyrinth-pattern microridges on the apical surface; these cells help to hold mucus film over the epithelial membrane and thereby protect the epithelium from harmful substances. The mucous cells are distributed in between the stratified epithelial cells of the olfactory lamellae. The mucus covering the olfactory lamellae constitutes an important medium in which odorants are dif- 
fused. On the other hand, the mucin probably helps in binding microscopic debris, which is ejected through the posterior nostrils.

Rita rita is a bottom-dwelling carnivorous catfish and subsists on molluscs, insects, crustaceans, and small fish. Therefore, the dense population of ciliated receptor cells is of special interest to enable the fish to detect food. On the other hand, the microvillous cells in the elongated olfactory epithelium use hormones as pheromonal cues to coordinate reproductive behaviours.

Acknowledgements: We are grateful to Dr. S. Chakraborty, the scientist-in-charge of the University Science Instrumentation Centre, The University of Burdwan, for his technical support in SEM analysis.

\section{REFERENCES}

BANNISTER L. H. 1965. The fine structure of the olfactory surface of teleostean fishes. Q. J. Microsc. Sci. 106: 333-342.

Belanger R. M., Smith C. M., Corkum L. D., Zielinski B. S. 2003. Morphology and histochemistry of the peripheral olfactory organ of the round goby, Neogobius melanostomus (Teleostei: Gobiidae). J. Morphol. 257: 62-71.

Bhute Y. V., Baile V. V. 2007. Organization of the olfactory system of the Indian Major Carp Labeo rohita (Hamilton): a scanning and transmission electron microscopic Study. J. Evol. Biochem. Physiol. 43: 342-349.

Chakrabarti P., Ghosh S. K. 2010. Histoarchitecture and scanning electron microscopic studies of the olfactory epithelium in the exotic fish Puntius javanicus (Bleeker). Arch. Pol. Fish. 18: 173-177. doi: 10.2478/v10086-010-0019-7.

Doroshenko M. A., Motavkin P. A. 1986. Olfactory epithelium of marine fishes in scanning electron microscopy. Acta. Morphol. Hung. 34: 143-155.

Doving K. B., Dubois-Dauphin M., Holley A., Jourdan F. 1977. Functional anatomy of the olfactory organ of fish and the ciliary mechanism of water transport. Acta. Zool. 58: 245-255. doi: $10.1111 / \mathrm{j} .1463-6395$.

Ferrando S., Bottaro M., Pedemonte F., De Lorenzo S., Gallus L., Tagliafierro G. 2007. Appearance of crypt neurons in the olfactory epithelium of the skate Raja clavata during development. Anat. Rec. (Hoboken) 290: 1268-1272. doi: 10.1002/ar.20584.

Ghosh S. K., Chakrabarti P. 2009. Cellular architecture and functional aspects of the olfactory rosette of Wallago attu (Bleeker). Turk. J. Fish. Aquat. Sci. 9: 187-190. doi: 10.4194/trjfas.2009.0210.

Ghosh S. K., Chakrabarti P. 2010. Cellular organisation and functions of the olfactory epithelium of pearl spot Etroplus suratensis (Bloch): a light and scanning electron microscopic study. Folia Morphol. 69: 154-159.

Gon O., Fishelson L. 2009. Nasal olfactory organs and olfactory bulbs in Blennies. In: The biology of Blennies (Patzner R. A., Goncalves E. J., Hastings P. H. A., Kapoor B. G., Eds), pp. 118-213, Science Publishers, Enfield, NH, USA.

Hara T. J., ZielinsKi B. 1989. Structural and functional development of the olfactory organ in teleosts. Trans. Amer. Micro. Soc. 118: 183-194. doi: 10.1577/1548-8659.

JAKUBOWSKI M. 1981. Ultrastructure (SEM, TEM) of the olfactory epithelium in the wels, Siluris glanis L. (Siluridae, Pisces). Z. Mikrosk. Anat. Forsch. 95: 337-352.

Ma A. J., Wang X. A. 2010. Functional morphology of the olfactory organ of the tongue sole, Cynoglossus semilaevis. Chin. J. Oceanol. Limnol. 28: 209-217. doi: 10.1007/s00343-0109006-5. 
Mandal D. K., Roy D., Ghosh L. 2005. Structural organization of the olfactory epithelium of a spotted snakehead fish, Channa punctatus. Acta. Ichthyol. Piscat. 35: 45-50.

Ruzhinskaya N. N., Gdovskir P. A., Devitsina G. V. 2001. Chloride cell, a constituent of the fish olfactory epithelium. J. Evol. Biochem. Physiol. 37: 89-94. doi: 10.1023/A:1017526204623.

ShIRAI N., UtidA S. 1970. Development and degeneration of the chloride cell during seawater and freshwater adaptation of the Japanese eel Anguilla japonica. Zeitschr. Zellforsch. 103: 247-264.

Teichmann H. 1954. Vergleichende Untersuchungen an der Nase der Fishe. Z. Morphol. Oekol. Tiere. 43: 171-212.

Yамамото M. 1982. Comparative morphology of the peripheral olfactory organ in teleosts. In: Chemoreception in fishes (HARA T. J., Ed.), pp. 39-59, Elsevier, Amsterdam.

Yashpal M., Kumari U., Mittal S., Mittal A. K. 2006. Surface architecture of the mouth cavity of a carnivorous fish Rita rita (Hamilton, 1822) (Siluriformes, Bagridae). Belg. J. Zool. 136: $155-162$.

Zeiske E., Theisen B., Gruber S. H. 1987. Functional morphology of the olfactory organ of two carcharhinid shark species. Can. J. Zool. 65: 2406-2412. doi: 10.1139/z87-362.

Zeiske E., Theisen B., Breucker H. 1992. Structure, development, and evolutionary aspects of the peripheral olfactory system. In: Fish Chemoreception (HARA T. J., Ed.), pp. 13-39, Chapman and Hall, London.

Zeiske E., Kasumyan A., Bartsch P., Hansen A. 2003. Early development of the olfactory organ in sturgeons of the genus Acipenser: A comparative and electron microscopic study. Anat. Embryol. 206: 357-372. 